\title{
ГЕОГРАФИЯ
}

Светлой памяти

Эдуарда Аркадьевича Молостовского посвящается

УДК[502.3:631.416.8] (470.44 - 25)

\section{СТРУКТУРА И ДИНАМИКА ТЕХНОГЕННЫХ ГЕОХИМИЧЕСКИХ ПОЛЕЙ НА ТЕРРИТОРИИ САРАТОВА}

\section{В.З.Макаров, Э.А.Молостовский , Б.А.Новаковский ${ }^{1}$, О.В.Суровцева, А.Н.Чумаченко}

\author{
Саратовский государственный университет, \\ кафедра физической географии и ландшафтной экологии \\ E-mail: gis@sgu.ru \\ ${ }^{1}$ Московский государственный университет им. М.В. Ломоносова, \\ кафедра геоэкологии \\ E-mail: chumach@sgu.ru
}

В статье рассмотрены структура и динамика ореолов техногенных геохимических аномалий на территории Саратова по результатам исследований за последние пятнадцать лет.

Ключевые слова: экологический мониторинг, техногенные геохимические аномалии, урболандшафтное районирование, геоинформационное картографирование.

\section{Structure and Dynamics of Saratov City Geochemical Fields}

V.Z. Makarov, E.A. Molostovskiy, B.A. Novakovsliy, O.V. Surovtseva, A.N. Chumachenko

This article represents structure and dynamics of anthropogenic geochemical anomalies halos within Saratov city territory as a result of the last 15th years research.

Key words: ecological monitoring, anthropogenic geochemical anomalies, urbolandscape zoning, GIS mapping.

Постановка проблемы. В современном мире основная часть населения проживает в крупных и крупнейших городах и мегалополисах. Саратов относится к числу крупнейших городов Нижнего Поволжья. В двойном городе Саратов-Энгельс проживает более 1100 тыс. жителей.

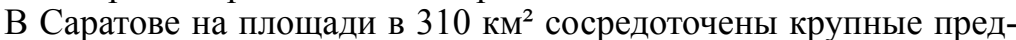
приятия химии, нефтехимии, нефтепереработки, стройиндустрии, машиностроения, энергетики, имеющие федеральное значение. На территории города размещено более 500 промышленных площадок, находятся нефтяной промысел и подземное газохранилище, работают два аккумуляторных завода.

Отметим, что в Саратове в настоящее время наблюдается процесс обострения экологических проблем, связанный с известным ослаблением контроля за выполнением природоохранных мероприятий на промышленных и транспортных предприятиях, резким увеличением плотности транспортного потока на городских улицах, хаотичной застройкой и уплотнением исторического центра и, как следствие, загрязнением воздушного бассейна города, хронической нехваткой средств на обновление инженерной инфраструктуры и жилого фонда, сокращением и без того малого количества зеленых насаждений общего пользования и пр.
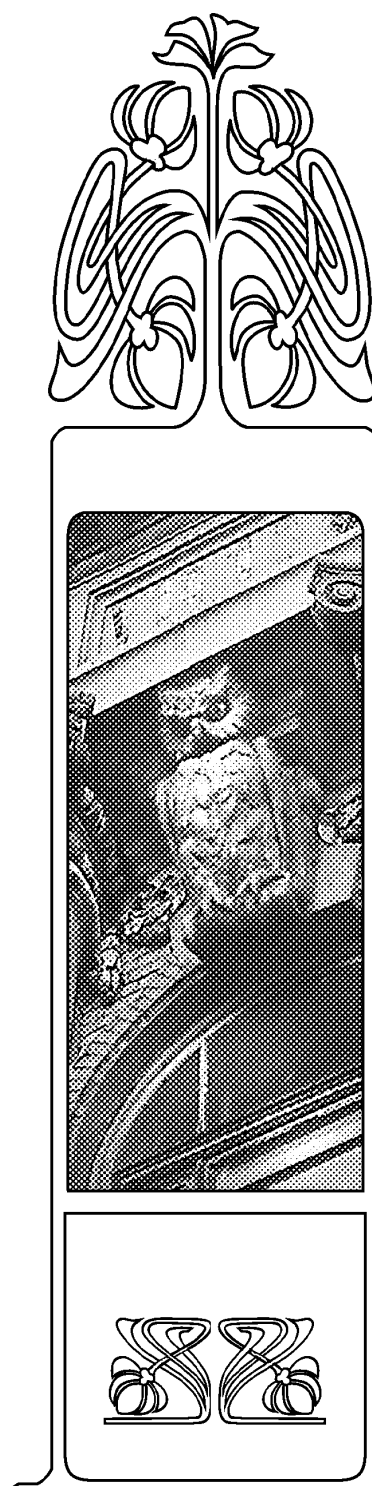

НАУЧНЫЙ
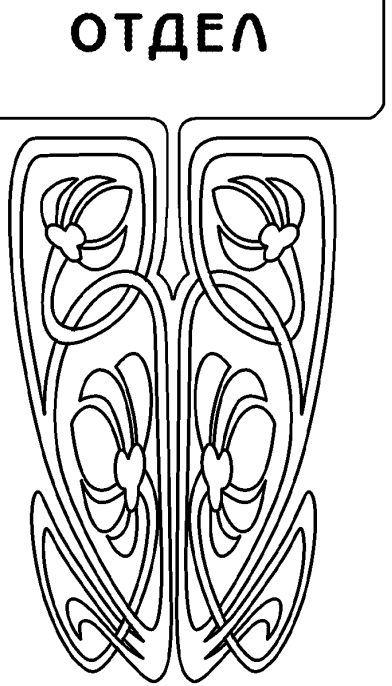
Поэтому постоянное наблюдение за экологической ситуацией в городе является актуальной, требующей постоянного внимания проблемой городского муниципалитета и общественности.

Некоторые результаты ранее выполненных ландшафтно-геохиических исследований. В начале 90-х гг. прошлого столетия в Саратове была предпринята первая и пока, к сожалению, единственная попытка комплексного и достаточно глубокого изучения состояния санитарно-гигиенической и геоэкологической обстановки в городе. Речь идет о специализированной экологической программе «Экологический мониторинг Саратова» (ЭМоС), принятой городскими властями в 1992 году. Полевые и камеральные работы носили комплексный характер и включали разнообразные геоэкологические исследования на модельных площадках и полигонах-трансектах, специализированные микро- и мезоклиматические наблюдения, литохимическое и гидрохимическое опробование, неоднократную снегогеохимическую съемку, геоморфологические наблюдения, геоботанические и биоиндикационные исследования, гидрологические и гидрогеологические изыскания, социологические опросы, медико-экологический анализ, историко-архивные разыскания. Наиболее детальные многолетние разносезонные полевые работы были выполнены сотрудниками географического (лаборатория урбоэкологии и лаборатория геоинформатики и тематического картографирования) и геологического факультетов СГУ в Саратове и пригородной зоне.

В процессе выполнения этих работ В.3. Макаровым с сотрудниками лаборатории урбоэкологии была разработана и проверена на практике концептуальная основа и методология комплексного геоэкологического изучения урбанизированных территорий [1]. Предложенный Макаровым подход урболандшафтного районирования территории города, элементарной таксономической единицей которого является урболандшафтный участок, взят за основу при выделении ключевых участков исследования Саратова во все последующие годы. Важнейшее внимание в 90-е гг. было уделено разработке концепции геоинформационного эколого-географического картографирования городов, методов и приемов создания природноэкологических, техногенно-экологических и социально-экологических карт городов с применением ГИС-технологий и данных дистанционного зондирования Земли [2, 3].

Выполнение программы ЭМоС позволило получить значимые практические результаты. В частности, были изучены и картографированы основные свойства и формы проявления урбогенеза на территории Саратова и других крупных городов, подтвержден уже известный высокий уровень техногенной концентрации химических элементов, превращающий городскую территорию в единый геохимический ореол рассеяния, выявлена высокая контрастность, своеобразная «пятнистость» геохимических аномалий на городской территории и в ближнем пригороде, обнаружена, с одной стороны, активная динамика переноса и перераспределения загрязняющих веществ между удаленными друг от друга «грязными» и «чистыми» участками, а с другой - локально-точечный и локально-линейный характер высоких уровней загрязнения на промышленных площадках, городских свалках и вокруг них, а также вдоль транспортных коридоров и в овражно-балочной сети. Это свидетельствует о сложных процессах миграции загрязняющих веществ, связанных с особенностями природноландшафтных и градопланировочных факторов, со спецификой промышленного производства и состоянием коммунального хозяйства Саратова.

Неоднократные снегогеохимические и литохимические съемки городской территории обнаружили явное преобладание нейтрально-щелочных показателей в почвенном покрове и снеговой воде, что свидетельствует об урбогенном защелачивании природных сред, несмотря на известные «кислые» выбросы двуокиси серы при работе предприятий теплоэнергетики. Преобладание щелочного буфера в почвах Саратова является положительным фактором, так как ограничивает миграционную подвижность опасных биоцидов, например свинца. Результаты этой работы использованы в различных отчетах, докладах и научных публикациях [4].

В 2000 г. литохимическое исследование почв и грунтов территории Саратова было продолжено сотрудниками НИИ геологии СГУ совместно со специалистами Музея В.И.Вернадского РАН [8] в рамках соглашения с «Институтом устойчивых сообществ» (ISC, США). Проведенные работы позволили нам сформулировать следующие выводы.

1. Анализ распределения валовых концентраций тяжелых металлов по территории Саратова выявил приоритетные для данного города элементы-загрязнители. Это кадмий, свинец, цинк, медь, никель.

2. Выявлена высокая степень подвижности указанных металлов 1-2-го класса опасности, что требует незамедлительной реакции природоохранных служб. Были выделены сильно подвижный кадмий (41\% подвижных форм), цинк и свинец (соответственно, 21,75\% и 21,7\% проб).

Наиболее загрязненными оказались промышленные, селитебные и промышленно-селитебные участки, приуроченные в основном к элювиальноаккумулятивному типу геохимических ландшафтов [5].

Результаты почвенно-геохимических работ. В 2007 г. сотрудниками лаборатории урбоэкологии и регионального анализа и лаборатории геоэкологии географического и геологического факультетов СГУ по заказу Комитета охраны окружающей среды и природопользования Саратовской области было осуществлено ещё одно 
эколого-геохимическое обследование почв на территории Саратова с целью определения их загрязнения солями группы тяжёлых металлов (1-3-го класса опасности) и нефтепродуктами. Подчеркнем, что обследование городских земель для оценки их загрязнения нефтепродуктами было выполнено впервые. Исследования проводились под научным руководством профессора В.3. Макарова, ответственными исполнителями работ были профессор Э.А. Молостовский и профессор А.Н. Чумаченко. Отбор почвенных проб, их привязка на местности, документальное оформление и пробоподготовка осуществлялись студентами-практикантами СГУ Е.Н.Михеевым, И.Ю.Ивановой и А.В. Величко под руководством и при непосредственном участии И.Ю. Фролова, М.В. Решетникова. Им всем авторы данной статьи приносят глубокую благодарность.

Методика исследований определялась содержанием технического задания, государственными стандартами по контролю загрязнения почв и методическими рекомендациями по проведению эколого-геохимических исследований. Согласно этим документам необходимо было:

- провести геохимическое обследование почв и почвогрунтов в разных урболандшафтных зонах территории г. Саратова;

- провести оценку современного экологогеохимического состояния (ЭГС) городских почв по отношению к ПДК, ОДК и фоновым параметрам;

- установить соотношение современного ЭГС почв и почвогрунтов городской территории с ЭГС прошлых лет в различных урболандшафтных выделах;

- построить серию эколого-геохимических карт;

- создать почвенно-экологическую карту и синтетическую ландшафтно-геохимическую карту городской среды по данным аналитических карт.

- создать геоинформационную экологогеохимическую модель территории Саратова.

В подготовительный период были проанализированы отчётные материалы литогеохимических исследований 1992-1993 гг. и 2000 года. На их основе с учётом положения и интенсивности известных аномалий тяжёлых металлов, рельефа, розы ветров и урболандшафтной структуры города разработана схема опробования.

В соответствии с задачами исследования было определено семь репрезентативных полигонов (рис. 1). Четыре наиболее крупных полигона расположены в районах, где в процессе предыдущих исследований были выявлены устойчивые площадные аномалии тяжёлых металлов высокой интенсивности. Три полигона были заложены в относительно чистых окраинных районах много- и малоэтажной жилой застройки. Ниже приводятся краткие характеристики полигонов обследования, включённых в литохимическое опробование.

Полигон № 1 площадью 8-10 км² расположен близ южной границы города на вершине и склонах горы Увек (контуры полигона образуют почти правильный четырёхугольник). На территорию полигона попадают посёлки: Нефтяной, Новый Увек, Увек Береговой и Увек Ивановский, а также Увекская нефтебаза и санитарно-защитная зона ОАО «Саратовский НПЗ».

Полигон № 2 общей площадью 11,5 км² расположен в северной части Заводского района в зоне промышленных предприятий ОАО «Завод АИТ», ОАО «Саратовский авиационный завод», OАО «Литий-Элемент» и др. Его контуры вытянуты вдоль берега Волгоградского водохранилища. На территории полигона расположены жилые посёлки Юриш, Лесопильный, Улеши и жилые микрорайоны многоэтажной застройки. Полигон пересекает железная дорога со станциями Саратов-3, Лесопильный и Князевка.

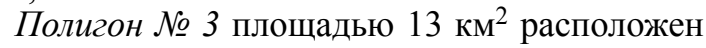
в Кировском и Фрунзенском районах с захватом части Волжского района. В него входит большая часть густонаселённого исторического центра города, а также территории посёлков Завокзальный, 1-й Пугачёвский, Детский парк и парк Липки, скверы по улицам Астраханская и Рахова; площадки промышленных предприятий «Электроисточник», «Серп и Молот», железнодорожных станций Саратов-1, Саратов-2, Локомотивное депо.

Полигон № 4 площадью 14 км² расположен в северной части Ленинского района города, в зоне предприятий группы компаний «Объединённые стекольные заводы Саратова», ГНПП «Контакт», $\mathrm{OAO}$ «Рефлектор». На эту территорию попадают также жилые районы 5-го и 6-го кварталов, пос. Северный, ВСО и Елшанка.

Полигон № 5 площадью 3 км² расположен в средней части склона Лысогорского плато, в жилых районах 2-й и 3-й Дачной. Промышленные предприятия отсутствуют.

Полигон № 6 площадью 3,5 км² расположен в районе Соколовой горы и включает пос. Соколовогорский, Новосоколовогорский, совхоз «Комбайн» и микрорайон Юбилейный. На водораздельной части Соколовой горы расположен парк Победы, на восточном склоне - нефтепромысел (Соколовогорский) и садовые участки.

Полигон № 7 площадью 5,5 км² расположен в северной части города. Включает пос. Мирный и Солнечный. Промышленные предприятия здесь практически отсутствуют.

На этих полигонах было отобрано 100 литогеохимических проб, что позволило выполнить в общей сложности 1200 аналитических определений, состав которых распределился следующим образом:

- определение валовых содержаний $\mathrm{Cu}, \mathrm{Zn}$, $\mathrm{Cd}, \mathrm{Ni}, \mathrm{Pb}, \mathrm{As}, \mathrm{Hg}-700$ анализов;

- определение концентраций подвижных форм $\mathrm{Cr}, \mathrm{Cu}, \mathrm{Zn}, \mathrm{Ni}-400$ анализов;

- определение нефтепродуктов - 100 анализов.

Аналитические работы выполнялись в аккредитованных лабораториях Государственной 


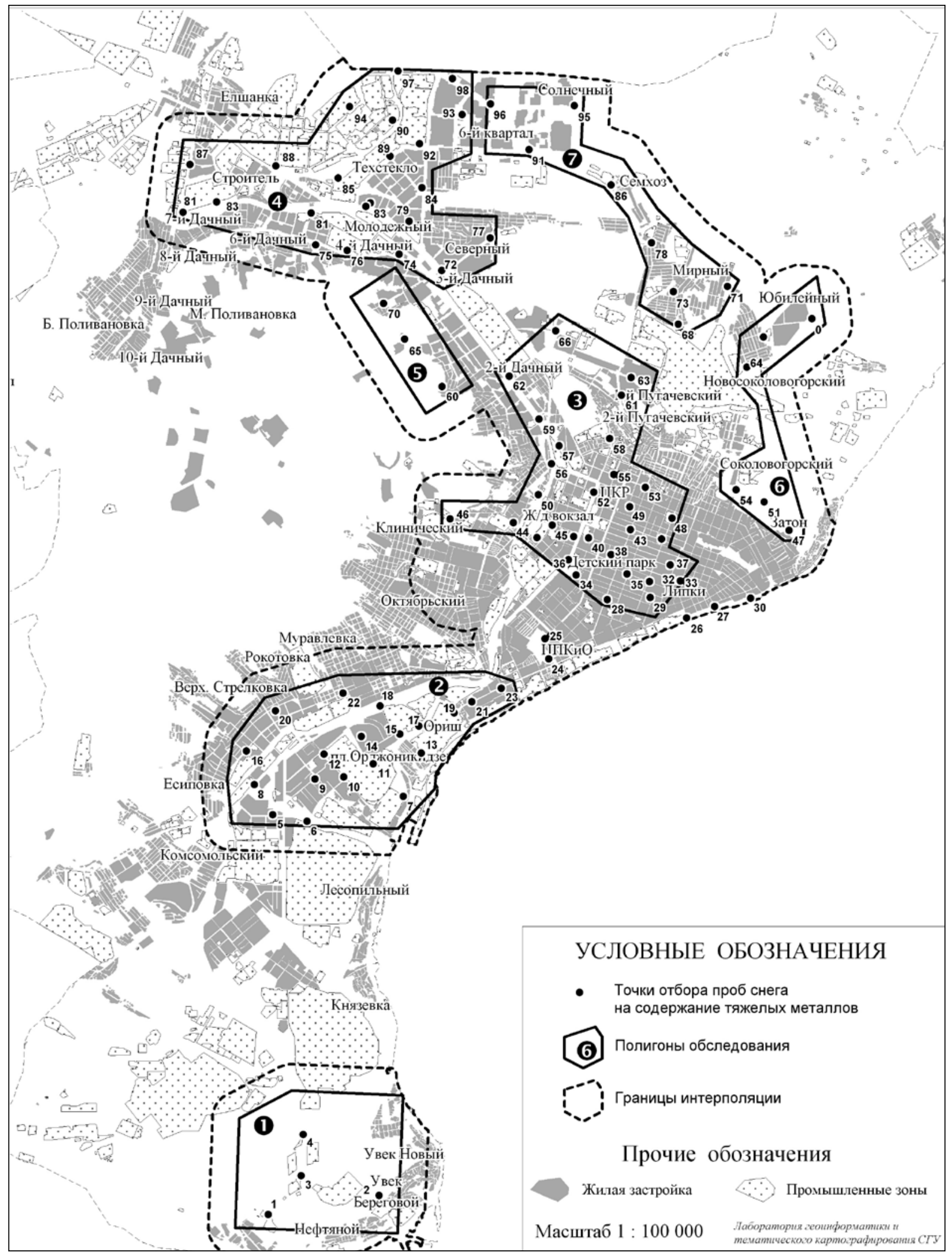

Рис. 1. Карта фактического материала 
станции агрохимической службы «Саратовская» и филиале «ЦЛАТИ по ПФО».

На основе полученных аналитических результатов были составлены детальные геохимические карты 7 исследовательских полигонов масштаба 1:20 000 и подготовлены обобщающие схемы масштаба 1:100 000 на всю территорию города (рис. 2).

В качество примера рассмотрим полученные результаты по некоторым химическим элементам и их ассоциациям.

Ртуть - валовая форма. Ртуть обнаружена во всех пробах в концентрации от 0,02 до 1,25 мг/кг при фоне в 0,026 мг/кг. В 63\% почвенных проб содержание ртути не достигает трёхфонового порогового уровня $(0,078 \mathrm{Mг} / к г)$, от которого определялись геохимические аномалии.

Её воздействием в той или иной мере затронуты все 6 административных районов города, но в основном это южные части Кировского, Фрунзенского, Волжского и Октябрьского районов. Подавляющее большинство проб с повышенным содержанием ртути было отобрано на территории исторического центра города. Геохимическая аномалия полностью охватывает центр города. Юговосточный край аномалии примыкает к городской набережной, где прослеживается более чем на 5 км от устья Глебучевого оврага до пос. Улеши. От Набережной Космонавтов аномалия протягивается к северо-западу почти до 2-й Дачной остановки. Общая площадь аномалии -25-27 км².

Главная аномалия обладает концентрической зональностью, с последовательным снижением величины Кс от 30-50 единиц в ядре до $3-5$ на периферии. На общем фоне выделяется несколько локальных и точечных аномалий с Кс равным 5-10 единицам, которые в совокупности с локальными незагрязнёнными участками формируют сложную мозаичную структуру основного ртутного поля Саратова. Основная часть изученной территории практически не затронута ртутным загрязнением за исключением двух слабоинтенсивных точечных аномалий на полигонах № 4 и № 7 в Ленинском районе.

Причина широкого загрязнения исторического центра города ртутью не имеет однозначного объяснения. Впервые центральная аномалия в близкой конфигурации и интенсивности была установлена при почвенно-геохимических работах в рамках программы ЭМоС в 1992-1993 гг., когда в качестве возможного источника выбросов была названа СарГРЭС, но это предположение не было подтверждено фактическим материалом. В 1994 г. саратовским городским Комитетом по охране окружающей среды были проведены специальные исследования, по выяснению причин ртутного загрязнения центрального района Саратова. Были выявлены многочисленные рассеянные источники локального загрязнения почв ртутью за счёт выбросов из вытяжных систем учебных лабораторий, разбитых термометров в детских учреждениях и больницах, выброшенных ртутных ламп и пр. [9].

Отсутствие ртутных аномалий на территориях Заводского и Ленинского районов исключает возможность загрязнения центральной части города за счёт сторонних промышленных выбросов. Аномалия имеет, несомненно, местное происхождение и возникла вследствие элементарной санитарной небрежности населения.

Интенсивность аномалии, установленная по сопоставлению с местным фоновым уровнем, не представляет сколько-нибудь значимой токсикологической опасности, поскольку максимальное содержание ртути не достигает уровня предельно допустимых концентраций.

Мылиьяк - валовая форма. Мышьяк обнаружен во всех почвенных пробах в концентрациях от 1,5 до 8,8 мг/кг при местном фоне 2,5 мг/кг. В $19 \%$ проб его концентрация ниже фоновых, у $64 \%$ содержание мышьяка не достигает двойного фона (5мг/кг), который был принят в качестве порогового уровня для выделения аномалий. К разряду аномальных с Кс >2 единиц относятся 17 \% проб, которые в основном сосредоточены в северной и северо-восточной частях городской территории в пределах Ленинского и Волжского районов (Елшано-Гусельская равнина, Соколовогорское плато). Основная часть проб с повышенным содержаниям мышьяка была отобрана на полигонах № 4, 6 и 7. На центральном полигоне № 3 обнаружены 2 точечные аномалии. В почвах южной и центральной частей города (Заводской, Октябрьский и Кировский районы) мышьяк присутствует в концентрациях ниже порогового уровня.

В зоне повышенного загрязнения зарегистрирована цепочка локальных (от 2 до 3,5 км²) аномалий, которая трассируется по крутой дуге через полигоны № 6, 7 и 4 от Соколовогорского поднятия до Золотой долины в северо-западной части Ленинского района. Все аномалии отмечены слабой интенсивностью со значениями Кс в пределах 2-3 единиц.

Поскольку фоновая концентрация мышьяка (2,5 мг/кг) превышает его ПДК (2 мг/кг), при построении геохимических карт был использован второй показатель. Построенные на базе ПДК карты геохимических аномалий позволили выявить в центральной части города (полигон №3) дополнительно несколько точечных аномалий с Кс = 2-3 ПДК. Основная зона загрязнения отчётливо выделяется в форме описанной выше дуги шириной от 1 до 2 км, которая прослежена на протяжении около 15 км от Соколовой горы до Золотой долины. В этой зоне Кс пределах от 2 до 3 ПДК с локальными разобщёнными аномалиями с Кс в 3 и более ПДК.

Столь масштабное загрязнение городской территории соединениями мышьяка установлено впервые. При работах 1992 - 1993гг. эмиссионным спектральным анализом были выявлены 10 рассеянных по всему городу кадмиевых аномалий в 


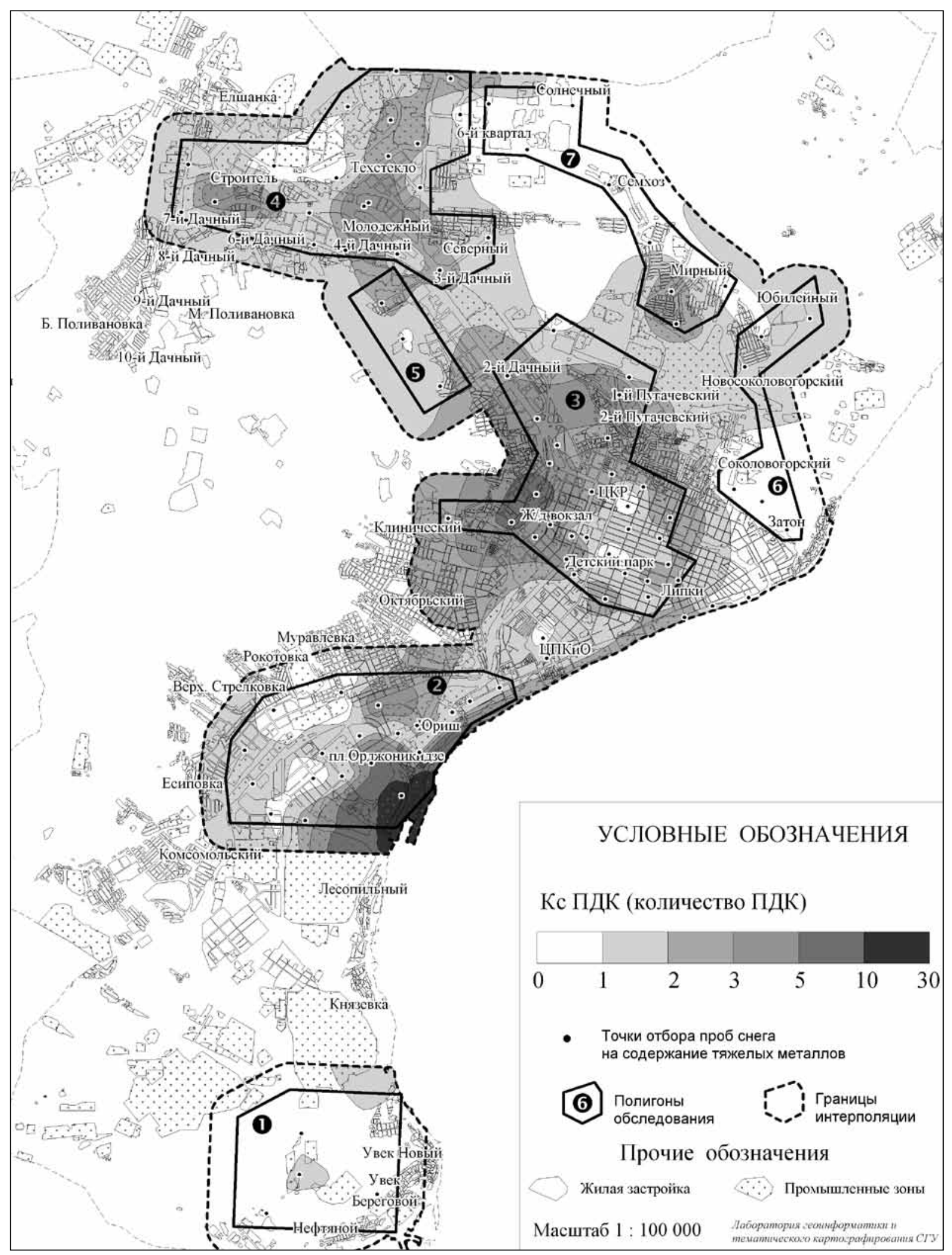

Рис. 2. Превышение ПДК свинца 
концентрациях с двукратным превышением фона. Сделать сколько-нибудь внятные выводы на этом материале было невозможно, а при почвенногеохимических работах в 2000 г. мышьяк не определялся. Для выявления возможных источников загрязнения территории города мышьяком необходимы дополнительные, более детальные исследования.

Кадмий-валовая форма. Кадмий обнаружен во всех пробах в концентрациях от 0,27 до 50,4 мг/кг при фоновом значении в 0,23 мг/кг. Большая часть (54 \%) проб содержит кадмий в концентрациях меньших порогового уровня $(0,69$ мг/кг). В основной массе резко выделяется группа из двух десятков проб с интенсивным кадмиевым загрязнением - от 2 до 50 мг/кг.

На обследованной части городской территории выделены четыре пространственно разобщённых аномалии кадмия .

Аномалия № 1 площадью около 6 км² выделена на вершине горы Увек в пределах полигона № 1 по четырём точкам. Точные контуры её не установлены. Аномалия имеет концентрически зональную структуру с Кс = 219 в центральной части. На периферии коэффициенты концентрации постепенно снижаются до порогового значения $($ Кс = 3). Район полигона № 1 представляет собой многолетнюю залежь с плотным разнотравнозлаковым покровом и редкими кустарниками. На удалении 0,6-0,8 км от точек отбора расположены ёмкости Увекской нефтебазы. Промышленные предприятия отсутствуют.

Аномалия № 2 находится в северной части Заводского района в пределах крупного промышленного узла в составе заводов АИТ, САЗ, Зуборезных станков и др. В непосредственной близости от предприятий расположены жилые кварталы и многочисленные детские учреждения. Установленная при настоящих работах площадь кадмиевой аномалии превышает 10 км², что практически равноценно территории полигона № 2 . Отчётливо выражен концентрически зональный характер техногенного загрязнения, центром которого являются ОАО «Завод автономных источников тока» (ЗАИТ) и ОАО «Литий-элемент». В центральной части аномалии, в санитарно-защитной зоне ЗАИТ, Кс приближается к 200 единицам, на периферии, в 1,5-2 км от центра, коэффициенты концентрации снижаются до значений, близких к пороговому уровню.

Аномалия № 3 фактически является продолжением аномалии в пределах исторического центра города, где занимает западную часть полигона № 3. Она представлена субмеридиональной неправильной формы полосой с извилистыми контурами, которая прослеживается на 10 км от берега Волгоградского водохранилища до южной границы Ленинского района. Ширина аномальной зоны в южной части достигает 1,5-2 км, на северном её окончании сужается до 0,5 км. Интенсивность загрязнения почв кадмием в пределах аномалии
№ 3 невелика. Значения Кс в её пределах варьируют в пределах от 3-5 единиц от фона, лишь в районе расположения завода «Электроисточник» намечается локальная аномалия площадью около 1 км$^{2}$ с Кс до 29 единиц.

Аномалия № 4 находится в северо-западной части Ленинского района в границах полигона № 5. Пространственно сопряжена с промзонами заводов «Контакт», «Рефлектор» и др. Аномалия незначительной интенсивности $($ Кс $=3-5$ единицам), её площадь порядка 2-2,5 км².

Единичные точечные аномалии кадмия близ пороговой интенсивности, выявленные в разных районах города, не имеют сколько-нибудь заметного значения для техногенного геохимического поля города. Геохимическая карта кадмия, построенная на базе предельно допустимых концентраций, сходна с картами, за основу построения которых взята концентрация природного фона.

Предприятия-загрязнители для большинства аномалий очевидны. Аномалии № 2 и № 3 являются производными аэрозольных выбросов завода автономных источников тока (ЗАИТ). Локальная аномалия на полигоне № 3 возможно связана с заводом «Электроисточник», источник аномалии № 4 - одно из предприятий ВПК Ленинского района. Достоверный источник образования интенсивной аномалии № 1 не установлен. Отсутствие промышленных предприятий в этом районе даёт основание для предположения о вторичном характере этой аномалии и её возможной связи со старыми несанкционированными захоронениями промышленных отходов.

Сопоставление современной карты с материалами литогеохимической съёмки 2000 г. свидетельствует о сохранении общей структуры геохимического поля кадмия на всей городской территории. Различия в деталях неизбежны из-за неравноценности фактологической базы 500 проб в 2000 г. на 100 проб в 2007 году.

В целом намечается явный спад загрязнения городских почв кадмием по сравнению с предыдущими съёмками, который наиболее ощутим в центральной и северной частях города, удалённых от завода автономных источников тока.

Свинец - валовая форма. Свинец является одним из наиболее распространённых металлов в геохимическом поле Саратова. Его присутствие установлено во всех проанализированных пробах в концентрациях от 0,37 до 42 мг/кг, при этом в $15 \%$ проб его содержание не достигает порогового уровня, равного трём фоновым концентрациям (Кс $=3 \Phi=25$ мг/кг). В основной массе (55\%) проб Кс варьирует от 3 до 10 фоновых содержаний. Значительная (30 \%) группа проб с повышенным содержанием свинца (Кс от 10 до 42) сосредоточена обычно в центральных частях крупных аномалий.

В общем поле свинцового загрязнения отчётливо индивидуализирована лишь аномалия на г. Увек. Она занимает центральную и северо- 
западную части полигона №1. Аномалия слабой интенсивности (Кс = 3-6), её площадь около 3 км².

По материалам литогеохимической съёмки 2000 г. Увекская аномалия узкой полосой пунктирно прослеживается до северной части Заводского района, где сливается с аномальной зоной у пос. Юриш. При работах 2007 г. этот слабозагрязнённый участок протяжённостью около 5 км не обследовался.

Основная часть изученной территории находится в пределах единого геохимического поля, которое включает территории полигонов № 2, 3, 4 полностью и полигонов № 5, 6 и 7 частично. Южная часть геохимического поля совпадает территориально с полигоном №2 на севере Заводского района. Здесь полоса повышенных содержаний свинца $(\mathrm{Kc}=3-10)$ прослеживается к северо-востоку вдоль берега Волги на протяжении 8 км вплоть до устья Глебучева оврага.

От берега р. Волги аномальная зона трассируется к северо-западу вдоль денудационного уступа Лысогорского плато на протяжении 12 км вплоть до 6-й Дачной остановки. Её суммарная площадь приближается к 70 км$^{2}$, но полностью главное свинцовое поле не оконтурено. На его восточном фланге намечается полоса минимального загрязнения $($ Кс $=3-5)$, фрагменты которой зарегистрированы на полигонах № 6 и № 7. На основной территории поля значения Кс лежат в пределах 5-10 единиц.

В пределах полигонов № 2, 3, 4 выделяются три зоны повышенного загрязнения. Южная зона представлена локальной (2-3 км²) аномалией, расположенной близ берега Волги у пос. Юриш. $\mathrm{B}$ её центральной части Кс $=40$, на флангах он последовательно снижается с 19 до 5 единиц.

Основная зона повышенного свинцового загрязнения выявлена в западной части полигона № 3 в виде субмеридиональной полосы размером $1-1,5$ х 5 км, прилегающей к промзоне завода «Электроисточник». Коэффициенты концентраций в пределах этой наиболее крупной аномалии варьируют в пределах 10-20 единиц.

Третья локальная (около 2 км$^{2}$ ) аномалия с Кс в интервале 10-15 единиц зарегистрирована на полигоне № 4 в северо-западной части Ленинского района. Пространственно она тяготеет к промзоне заводов «Контакт», «Рефлектор» и др. Карта, построенная на основе предельно допустимых концентраций, по конфигурации и структурно близка к карте, базирующейся на фоновых показателях. Загрязнение основной части городской территории варьирует в интервале 1-1,5 ПДК, в перечисленных выше аномалиях - от 3 до 5 ПДК и лишь в южной аномалии в одной точке достигает 10 ПДК.

Согласно нормативам при оценке загрязнения земель валовыми формами свинца при концентрации меньше 1 ПДК последние относятся к категории допустимого загрязнения, концентрации от ПДК до 125 мг/кг классифицируется как низкий уровень загрязнения. При 4 ПДК валового содержания свинца выявленные ореолы относятся к разряду слабозагрязнённых площадей. Анализ составленных карт позволяет сказать, что жилые районы города попадают в зоны допустимого и низкого уровней загрязнения.

Сопоставление результатов проведённых исследований с данными 2000 г. свидетельствует о существенном снижении уровня загрязнения городских земель валовыми формами свинца. Эта тенденция проявлена в существенном сокращении площадей повышенного (10-30 фонов) загрязнения и значительном спаде значений Кс в центральных частях наиболее интенсивных аномалий.

Так, по данным 2000 г., в аномалии на севере Ленинского района имелось несколько ядер с Кс >

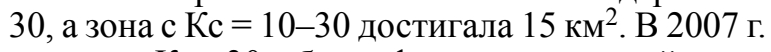
значения Кс в 30 и более фоновых значений здесь вообще не установлены, а зона с Кс $=10-30$ сократилась до 2-2,5 км².

В аномалии завода «Электроисточник» исчезли мелкие аномалии-сателлиты с Кс > 30, а площадь зоны с Кс =10-30 сократилась более чем втрое, с 25 до 6-7 км².

Цинк - подвижные формыл. Цинк входит в группу из четырёх металлов, для которых согласно техническому заданию проводилось определение валовых и подвижных форм нахождения. Цинк в подвижной форме зарегистрирован во всех пробах в концентрациях от 0,08 до 104 мг/кг при фоновом содержании 0,41 мг/кг.

Геохимические поля цинка в валовой и подвижной формах идентичны по площади и конфигурации, но поле подвижного цинка характеризуется более сложной дифференциацией и повышенным уровнем загрязнения.

Выделяются четыре аномалии распределения подвижных форм.

Аномалия №1 (Увекская) площадью в 4,5 км² в центральной части имеет Кс $=28,7$, ближе к периферии он снижается до 5,9 и менее.

Аномалия № 2 на севере Заводского района площадью более 11 км$^{2}$ пространственно тяготеет к территориям САЗ и ЗАИТ. Небольшая (около $\left.1 \mathrm{KM}^{2}\right)$ зона повышенного загрязнения $(\mathrm{Kc}=32-43)$ примыкает к берегу Волги, в основной части аномалии на площади около 9 км $^{2}$ Кс варьирует от 11 до 27 единиц.

Аномалия № 3 представляет собой сложнодифференцированное поле интенсивного загрязнения, которое прослеживается на протяжении 6 км от берега р. Волги до южной части Ленинского района. Матрица аномального поля образована зоной относительно умеренного загрязнения с Кс от 10 до 50 единиц.

На этом фоне отчётливо выделяется крупная

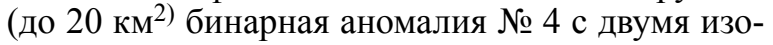
лированными ядрами с Кс $=172$ и 297. Первое - западное - ядро примыкает к промзоне завода «Электроисточник», второе находится на 2 км восточнее, в селитебном районе исторического 
центра города. По периферии зоны максимального загрязнения значения Кс снижаются до 30 единиц.

В северной части Ленинского района в пределах полигонов № 4, 5 и 7 на общем повышенном $($ Кс $>10)$ уровне намечается несколько локальных аномалий с Кс от 50 до 70 единиц.

Повышенные концентрации подвижных форм цинка характерны не только для промышленных зон, но и селитебных районов практически всего города.

При построении карты подвижных форм цинка относительно ПДК были зарегистрированы лишь четыре разрозненные точки с уровнем загрязнения в 1-1,2 ПДК и одна точка с Кс $=4$ ПДК. Таким образом, практически вся территория города по содержанию подвижных форм цинка относится к первому (допустимому) уровню загрязнения.

Подобным образом было проанализировано содержание в почвах всех исследуемых химических элементов и их ассоциаций, сделаны соответствующие выводы о размещении аномалий и их сравнение с аномалиями прошлого геохимического опробования.

Одним из результатов работы стало создание карт суммарного загрязнения почв (Zc) тяжёльми металлами (ТМ). Были построены четыре карты суммарного загрязнения $(\mathrm{Zc})$ для валовых и подвижных форм ТМ с расчётами уровня загрязнения от фоновых значений - Zc фон и предельно (ориентировочно) допустимых концентраций Zc ПДК и Zc ОДК.

Согласно карте суммарного загрязнения валовыми формами ТМ относительно фоновых концентращий TM большая часть городской территории относится к разряду слабого загрязнения c Zc фон.вал <16. На этом фоне выделяются три зоны повышенного загрязнения, которые трассируются по дуге вдоль денудационного уступа Лысогорского плато от Центральной УЛЗ Заводского района до Трофимовской УЛЗ на севере Ленинского района. Южная аномальная зона занимает часть полигона №1 и большую часть полигона № 2 . Небольшое ядро $\left(0,5\right.$ х 0,5 км$\left.^{2}\right)$ очень опасного загрязнения (Zc > 128) расположено несколько к северу от промзоны ЗАИТ. К разряду опасно загрязненных, со значениями Zc $32-128$, относится и территория площадью около 1,5 км$^{2}$, примыкающая к промзоне завода «Электроисточник».

Карта Zc пдк, одк по валовым формам даёт основание относить исследованную территорию к разряду допустимо загрязнённых с Кс $<16$. Локальная аномалия с опасным и умеренным загрязнением установлена лишь в Заводском районе, возле промзоны ЗАИТ.

Карта суммарного загрязнения подвижными формами ТМ относительно фона (Zc фон) свидетельствует о неблагоприятной экологической обстановке на большей части городской территории, которая почти полностью входит в зону опасного загрязнения с Zc в пределах 32-128.
На общем фоне выделяется несколько локальных зон чрезвычайно опасного загрязнения: точечная аномалия на вершине г. Увек, вероятно, обусловленная свалкой мусора, образованной в прошлые годы; территория в зоне влияния бывшего кожевенного завода; участки возле промзоны завода «Электроисточник», в районе улиц Кутякова, Посадского и других, прилегающих к Центральному рынку, железнодорожному вокзалу, пос. Юбилейный, в застройки между ул. Астраханской и Рахова, неподалеку от Детского парка и в некоторых других местах.

При анализе распределения значений Zc подвижных форм тяжёлых металлов относительно ПДК (ОДК) выяснилась практическая стерильность городской территории по этому показателю. Наиболее внушительно выглядит точечная аномалия на горе Увек (Zc = 5-7 ПДК). В центральной части города локальная слабая аномалия с Zc $=2-3$ ПДК зафиксирована в районе завода «Электроисточник», две точечные аномалии такой же интенсивности обнаружены в районах жилой застройки.

Сопоставление карт Zc ПДК, составленных в 2000 г. и 2007 г., однозначно указывает на сильное уменьшение уровня загрязнения тяжелыми металлами. Этот вывод подтверждается исчезновением крупной зоны чрезвычайно опасного и опасного загрязнения в Ленинском районе и существенным сокращением площадей в центре чрезвычайно опасного загрязнения города и на севере Заводского района. Следует заметить, что при однонаправленном тренде трансформации геохимического поля валовые и подвижные формы ТМ сохраняют прежние соотношения - загрязнение городских почв подвижными формами ТМ по результатам исследований в 2007г. относительно фонового уровня было и остаётся более интенсивным, нежели валовыми формами.

Загрязнение территории города нефтепродуктами. Обследование загрязнения территории города нефтепродуктами проводилось как в пределах полигонов, так и на трёх участках активного нефтяного загрязнения: на Увекской нефтебазе с прилегающим железнодорожным терминалом, в санитарно-защитной зоне нефтеперерабатывающего завода и на территории Соколовогорского нефтепромысла. Построены карты «надфонового» содержания нефтепродуктов по полигонам и карты превышений допустимого уровня на территории города.

Максимальные концентрации нефтепродуктов в почвах и грунтах отмечаются на территории наливного железнодорожного терминала у НПЗ $(84270$ мг/кг, Кс = 84,2), на верхнем ярусе Увекской нефтебазы (20300 мг/кг, Кс =20,3), у «Саратовводоканал» $(17970$ мг/кг, Кс $=17,9)$, у нефтеулавителя на Увекской нефтебазе (14380, 14870 , 17360 мг/кг, Кс = 14,3, 14,8, 17,3 соответственно).

Значительное нефтяное загрязнение почв выявлено в селитебной зоне города: на перекрестках 
ул.Большой Казачьей и ул.Пугачевская (13250 мг/кг, Кс $=13,2)$, ул.Соколовая и ул.Чапаева (12898 мг/кг, Кс $=12,8)$, на ул. Большая Горная у д/с № 18 $(10760$ мг/кг, Кс = 10,7). Высокие концентрации отмечены и на территории Соколовогорского месторождения (7704 и 10442 мг/кг, Кс = 7,7 и $10,4)$. На остальной территории города загрязнение нефтепродуктами несколько ниже, хотя и остается в основном достаточно высоким. Сильно загрязнены нефтепродуктами почвы и грунты центральной части города на участке от ул. Рабочая - ул. Астраханская до ул.Чапаева - ул. Соколовая (полигон № 3) - более чем в 5 раз. Несколько ниже (до 3 раз) загрязнение в районе ул.Б.Горная - ул. Танкистов - ул. Жуковского. Достаточно сильное загрязнение отмечено в пределах полигона № 7 $(5,2-6,5$ раза) в районе пос. Мирный - пос. Солнечный. Несколько ниже загрязнение в районе промзоны на севере Ленинского района (полигон № 4) - от 3,4 до 4,5 раз.

В целом необходимо отметить определенный пространственный характер распределения повышенного содержания нефтепродуктов на территории города. На юге загрязнение отмечается на восточном склоне г. Увек $(\mathrm{Kc}=1-20)$. Севернее загрязнены северные склоны возвышенности, на которой расположен испытательный аэродром САЗ $(\mathrm{Kc}=3-20$ раза). Далее зона нефтяного загрязнения тянется узкой полосой $(\sim 500-700$ м) вдоль берега p.Волги до центральной части города, где покрывает практически весь исторический центр города (Kc= = 1-13). Пространственно обособлена зона повышенного содержания, связанная с Соколовогорским нефтепромыслом $(\mathrm{Kc}=3-10)$. Достаточно слабо загрязнен Ленинский район в пределах полигона № $4(\mathrm{Kc}=2-3)$. Более сильное загрязнение отмечается в пос. Солнечном и в северной части пос. Мирного (Кс = 3-5) (полигон № 7). Наименее загрязненным является полигон № 5 в верхней части склона Лысогорского плато, в районе 3-й Дачной. Такая пространственная конфигурация позволяет говорить как о явных крупных загрязнителях городской среды нефтепродуктами, таких как Увекская нефтебаза, Соколовогорский нефтепромысел и множестве мелких, рассеянных по территории города. Однако ряд проб, отобранных около АЗС, действующих не один десяток лет, не показали существенного превышения концентраций нефтепродуктов относительно близлежащих точек.

Вопрос об источниках нефтяного загрязнения центральных районов города требует дальнейшего изучения.

В настоящее время трудно судить, какой из источников выбросов играет ведущую роль. Но следует отметить, что основные концентрации нефтепродуктов в почвах зарегистрированы в районах с интенсивным движением автотранспорта.

Полученные сведения указывают на значительную распространенность скрытого загрязнения почв нефтепродуктами. Оно выявляется лишь в процессе аналитических определений проб, которые при отборе не вызывают никаких подозрений. Высокие концентрации нефти обнаружены на вполне визуально благополучных участках южного склона Увекской гряды, где расположены хранилища одноимённой нефтебазы. Не обнаруживают внешне следов загрязнения и почвы центральных районов города, где выявлены многочисленные аномалии с концентрациями нефтепродуктов в Кс $=3-5$.

Заключение. Системное геоэкологическое изучение Саратова, начавшееся в первой половине $1990-$ х гг. по программе ЭМоС, позволило составить достаточно полное представление о техногенном геохимическом поле в почвах городской территории. В течение последующих семи лет город не получал достоверной геохимической информации о состоянии его территории.

Работы по эколого-геохимическому изучению почвенного покрова Саратова, выполненные в 2007 г., имеют принципиальное значение как в научно-прикладном, так и в организационноуправленческом плане:

1) с их постановкой в Саратове началось восстановление регулярной системы экологогеохимического мониторинга, необходимого для принятия обоснованных природоохранных решений и обеспечения устойчивого развития города;

2) получены материалы, свидетельствующие о кардинальных изменениях в структуре геохимического поля города, значительном сокращении его загрязнении солями токсичных тяжёлых металлов ( $\mathrm{Pb}, \mathrm{Zn}, \mathrm{Cu}, \mathrm{Cd}, \mathrm{Ni}, \mathrm{Cr}, \mathrm{Hg}$ и $\mathrm{As})$ за период 2000-2007 годов;

3) впервые получены данные о широком развитии на городской территории процесса загрязнения почв нефтепродуктами.

Перечисленные сведения имеют немаловажное значение для ориентации дальнейших эколого-геохимических исследований в условиях изменившейся техногенной обстановки.

Полученные результаты свидетельствуют о значительной мобильности техногенного литогеохимического поля тяжёлых металлов и способности почв к быстрому самоочищению. Эта тенденция свойственна всем тяжёлым металлам и отчётливо проявлена на всех модификациях карт Zc. В итоге Саратов, который 7-10 лет тому назад относился к группе городов активного загрязнения, в настоящее время перешёл в категорию умеренно и слабо загрязнённых объектов соединениями тяжёлых металлов.

На сегодня большинство промышленных предприятий перестали быть источником загрязнения тяжёлыми металлами. В этом плане полностью сохранили своё негативное значение лишь заводы «Электроисточник» и ЗАИТ, которые остаются экологически опасными в плане выбросов свинца, кадмия и никеля.

В сложившейся обстановке представляется целесообразным определённые изменения в структуре экологического мониторинга. Основными объектами наблюдения должны оставаться два 
упомянутых выше предприятия, промзоны которых и прилегающие территории должны подвергаться регулярному детальному обследованию почв в масштабе 1:10000 на специфические для них металлы $\mathrm{Cd}, \mathrm{Ni}, \mathrm{Pb}$. На остальной территории, как показывает опыт, можно ограничиться выборочными обследованиями почв через 5-6 лет. Тем не менее представляется оправданным смещение акцента на снеговую съёмку, результаты которой дают важную информацию о загрязнении природной среды в реальном режиме времени. Для получения информации о наличии тяжелых металлов снеговую съёмку можно проводить только в зонах заводов «Электроисточник» и ЗАИТ и их промышленных площадок. В общегородском масштабе номенклатура загрязнителей, подлежащих определению, должна быть пополнена нефтепродуктами, фенолом и рядом других специфических веществ.

\section{Библиографический список}

1. Макаров В.3. Ландшафтно-экологический анализ крупного промышленного города / Под ред. Ю.П. Селивёрстова. Саратов: Изд-во Сарат. ун-та, 2001.

2. Чумаченко А.Н. Эколого-географическое картографирование городов // Взаимодействие картографии и геоинформатики. М.: Научный мир, 2000.

3. Макаров В.3., Новаковский Б.А., Чумаченко А.Н. Эколого-географическое картографирование городов. М.: Научный мир, 2002.

4. О состоянии окружающей природной среды Саратовской области в 1997 году. Саратов, 1998.

5. Форма нахождения тяжёлых металлов в почвах г. Саратова и природоохранные решения / Ред. кол. С.П. Балашова и др. Саратов: Научная книга, 2001.

УДК [004:504:553.98] (470.44)

\section{ПРИМЕНЕНИЕ ГИС-ТЕХНОЛОГИЙ ПРИ ОЦЕНКЕ СТЕПЕНИ УСТОЙЧИВОСТИ ТЕРРИТОРИИ К ЗАГРЯЗНЕНИЮ НЕФТЬЮ И НЕФТЕПРОДУКТАМИ (На ПрИМере районов промышленной добычи нефти в Саратовской области)}

\section{А.В. Молочко}

Саратовский государственный университет, кафедра геоморфологии и геоэкологии E-mail: farik26@yandex.ru

Проведенное районирование территории промышленной нефтедобычи в Саратовской области с использованием геоинформационных технологий дает возможность выделять в рамках района исследования ареалы с разной устойчивостью к нефтяному загрязнению в зависимости от их принадлежности к типу местности и природной зоне.

Ключевые слова: добыча нефти, Саратовская область, устойчивость территории, нефтяное загрязнение, геоинформационные системы.

Regionalization of Saratov Region commercial Oil Production Region according the Territory resistance of Oil Pollution with GIS Supporting

\section{A.V. Molochko}

The regionalization of Saratov region commercial oil production region supporting with GIS is made possible to mark out (within the research region) several areas with different resistance to oil pollution subject to area types and native zones.

Key words: commercial oil production, Saratov region, territory resistance, oil pollution, GIS.

С каждым годом ухудшающееся геоэкологическое состояние Саратовской области при-

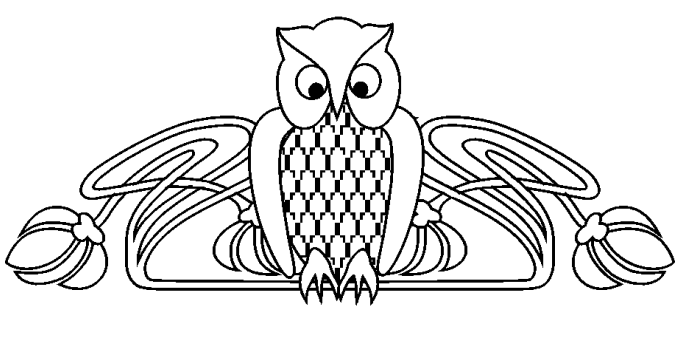

водит к необходимости проведения мер по его стабилизации и возможному улучшению, а также выявлению территорий, наиболее подверженных геоэкологическому риску. Поскольку нефтяная отрасль выступает одним из источников подобных рисков, проблема районирования территории промышленной нефтедобычи становится одним из наиболее важных вопросов в решении геоэкологических задач [1]. Для решения подобных задач целесообразно использование современных геоинформационных технологий, позволяющих существенно усовершенствовать процессы сбора, моделирования и визуализации геоэкологической информации, построения на основе ее обработки прогноза развития ситуации и выработке рекомендаций по дальнейшему использованию территорий.

Нефтедобывающая отрасль по суммарному годовому риску возникновения аварийных разливов нефти и нефтепродуктов, а также возникновению чрезвычайных ситуаций, способных привести к существенному влиянию на окружающую природную среду и человека, занимает одно из первых мест среди всех отраслей материального производства [2]. Нефтяная отрасль Саратовской области не является исключением.

Нефтедобывающая отрасль в Саратовской области существует уже более 55 лет. В настоящее время ежегодная добыча нефти в области составляет более 1400 тыс. т [3]. Основным до- 